\title{
REFLECTIONS ON VICTOR GORSHKOV'S FINAL WORK - "KEY ECOLOGICAL PARAMETERS OF IMMOTILE VERSUS LOCOMOTIVE LIFE"
}

\author{
S. L. Chown \\ School of Biological Sciences, Monash University, Melbourne, Victoria 3800, Australia \\ E-mail: steven.chown@monash.edu
}

Abstract. As the scientific literature explodes in its abundance, specialisation and forgetfulness, the temptation to quote from José Ortega $Y$ Gasset becomes irresistible: It would then be seen how, generation after generation, the scientist has been gradually restricted and confined into narrower fields of mental occupation [1]. Followed swiftly by cynical reflection on the publishing industry's massive profits. Victor Gorshkov's work immediately dispels these temptations. Here one sees the intellectual bounty offered by range - capability across and interest in multiple fields [2]. Among the very best of what science offers. Here I give a few examples.

Keywords: metabolic rate, biotic pump, hydrological cycle, immobile life, trace gases.

For citation: Chown S.L. Reflections on Victor Gorshkov's final work - "Key ecological parameters of immotile versus locomotive life". Russian Journal of Ecosystem Ecology. 2020;5(2). Available from: https://doi.org/10.21685/2500-0578-2020-2-4

УДК 574.4:581.5

\section{РАЗМЫШЛЕНИЯ ОБ ИТОГОВОЙ РАБОТЕ ВИКТОРА ГОРШКОВА - «ФУНААМЕНТАЛЬНЫЕ ЭКОЛОГИЧЕСКИЕ ПАРАМЕТРЫ НЕПОДВИЖНОЙ И ПЕРЕАВИГАЮЩЕЙСЯ ЖИЗНИ»}

\author{
С. Л. Чаун \\ Школа биологических наук, Университет Монаша, Австралия, Виктория 380о, Мельбурн \\ E-mail: steven.chown@monash.edu
}

\begin{abstract}
Аннотация. По мере быстрого роста количества, специализации и «забывчивости» современной научной литературы искушение цитировать Хосе Ортега-и-Гассета становится непреодолимым: «Люди науки, поколение за поколением, умещаются и замыкаются на все более тесном пространстве мысли» [1]. За этим следуют циничные размышления об огромных прибылях научных издательств. Работа Виктора Горшкова моментально рассеивает эти искушения. Здесь читатель получает интеллектуальное вознаграждение от соприкосновения с большим масштабом - исследовательских возможностей и заинтересованности автора в разнообразных областях [2]. Среди лучшего из того, что предлагает наука. В этом комментарии я обсуждаю несколько примеров.
\end{abstract}

Ключевые слова: метаболизм, биотический насос, круговорот воды, неподвижная жизнь, следовые газы.

The first of Victor Gorshkov's published research I encountered was work on metabolic rate variation in organisms, published in the Royal Society's Proceedings B [3]. As I read this paper, I realised I should have been looking out for his previous work. Given our similar interests in the scaling of metabolic rate, we soon ended up collaborating. The primary outcome was a demonstration, quite to my surprise, that mass-specific routine metabolic rate varies just 30 -fold $(0.3-8.8 \mathrm{~W} / \mathrm{kg})$ across organisms that vary in body mass by 20 orders of magnitude [4]. Despite some initial scepticism by the community, this result has been verified independently [5]. And it is one which offers fascinating additional perspectives [6].

Next, I came across Victor Gorshkov's work on the biotic pump of atmospheric moisture and its role in establishing and maintaining the hydrological cycle [7]. The approach provides an insightful combination of theoretical physics with empirical data showing just how important forests are for drawing water inland and keeping continents moist (Fig. 1). Initially controversial, again, these ideas are now fast reaching a broad 
audience. Over the past month I have thought repeatedly about their implications while watching Australia's south-eastern forests burn. What will this widespread forest destruction mean for an already parched continent, and one having just had its hottest and driest year on record [8] (since the early 1900s)? Occasionally the literature sees discussion of "terra-forming" other planets. We seem to be dismantling ours. Science to limit the change and prepare us for what we are already committed to is exceptionally important.

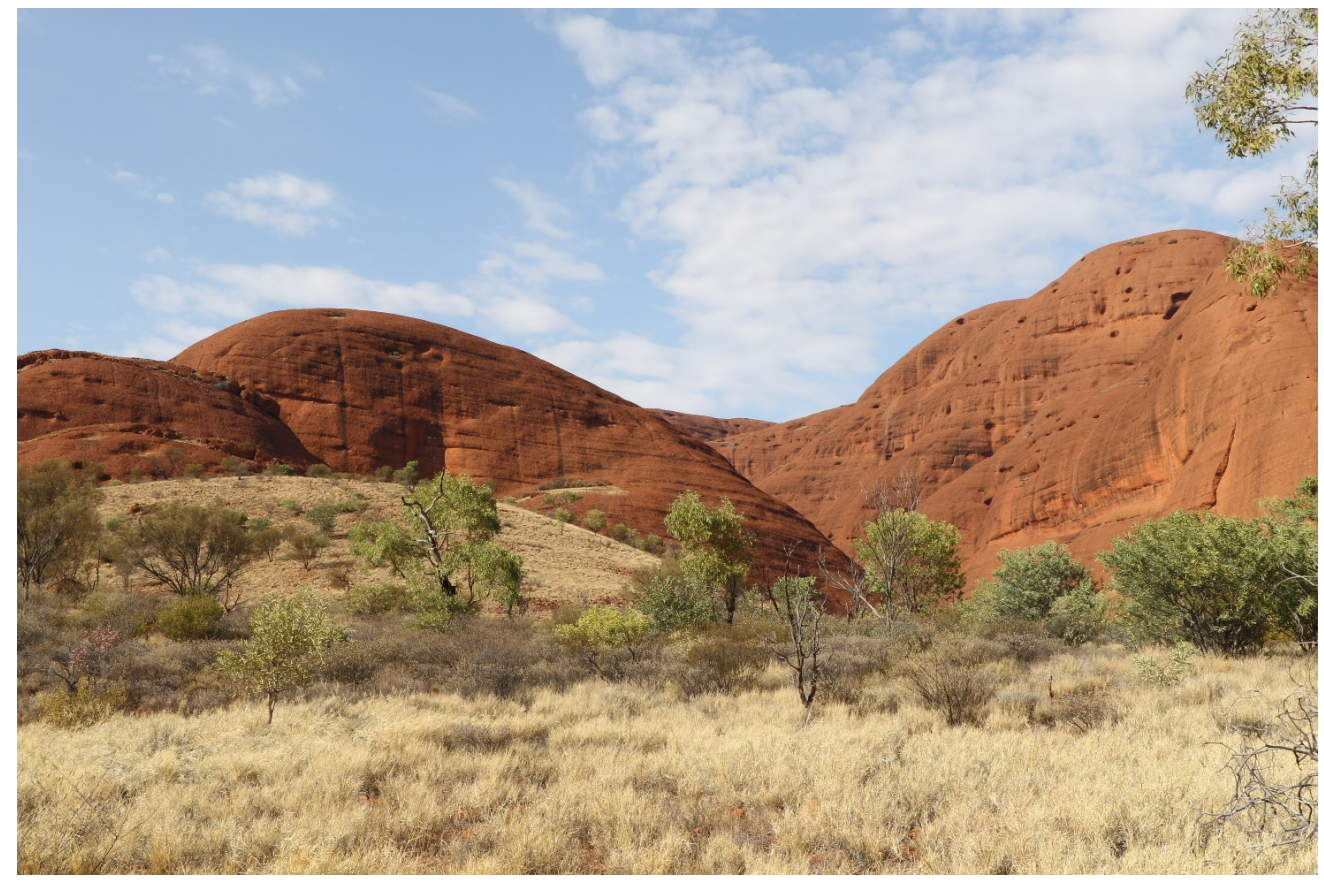

Fig. 1. The functioning and fate of terrestrial ecosystems, such as this one in central Australia (Kata Tjuta), have long been the subject of Victor Gorshkov's research (image by S. L. Chown)

And we now have this final contribution [9], published again with Victor's long-standing and close collaborator Anastassia Makarieva. The work sets out to change current understanding of the way our planet works by building cleverly on what we already accept as its generalities. Coming to grips with it demands range: consideration of multiple fields, assessment of numerous equations, scrutiny of assumptions, and scouring for evidence that supports or contradicts the empirical predictions. The thesis is deceptively straightforward: immobile life shows local self-organization, a process which occurs in all local systems globally. Mobile life has no such self-regulation. Indeed, it must use up resources locally, so causing profound ecosystem changes. Migration can mitigate the subsequent consequences for mobile life. Among the many fascinating implications of the idea is one highly relevant to us. A massively abundant and broadly distributed mobile species, such as ours, can destabilise the Earth system across its entire extent (Fig. 1).
The work is lively in its connections to multiple important questions - metabolic scaling [10], the demise of large mammals [11], and how information and energy interact in living systems [12]. It provides an opportunity for further testing too such as in systems that are based on chemosynthesis [13] or those, which may be quite common in some circumstances, that rely neither on photosynthesis nor on chemosynthesis, but on trace gas scavenging [14].

Few such broad approaches to explaining our world exist - we should welcome them, seize them and test them thoroughly. I believe that this is exactly what Victor Gorshkov would have wanted. And as has happened with his work on the similarity of life's metabolic rates, I expect that doing so would generate incredible benefit.

The death of a scholar is always a tragedy. But the tragedy here is lessened by the legacy that has been left through this final and remarkable transdisciplinary work.

\section{Библиографический список}

1. Ortega y Gasset, J. The Revolt of the Masses / J. Ortega y Gasset. - New York : W.W. Norton \& Co, 1932.

2. Epstein, D. Range: How Generalists Triumph in a Specialized World / D. Epstein. - London : Macmillan, 2019. 
3. Makarieva, A. M. Energetics of the smallest: do bacteria breathe at the same rate as whales? / A. M. Makarieva, V. G. Gorshkov, B.-L. Li // Proceedings of the Royal Society B: Biological Sciences. - 2005. - Vol. 272 (1577). P. 2219-2224. - DOI 10.1098/rspb.2005.3225.

4. Mean mass-specific metabolic rates are strikingly similar across life's major domains: Evidence for life's metabolic optimum / A. M. Makarieva, V. G. Gorshkov, B.-L. Li, S. L. Chown, P. B. Reich, V. M. Gavrilov // Proceedings of the National Academy of Sciences U.S.A. - 2008. - Vol. 105 (44). - P. 16994-16999. - DOI 10.1073/ pnas.0802148105.

5. Linking scaling laws across eukaryotes / I. A. Hatton, A. P. Dobson, D. Storch, E. D. Galbraith, M. Loreau // Proceedings of the National Academy of Sciences U.S.A. - 2019. - Vol. 116 (43). - P. 21616-21622. DOI 10.1073/pnas.1900492116.

6. Makarieva, A. M. Size- and temperature-independence of minimum life-supporting metabolic rates / A. M. Makarieva, V. G. Gorshkov, B.-L. Li, S. L. Chown // Functional Ecology. - 2006. - Vol. 20. - P. 83-96. - DOI 10.1111/ j.1365-2435.2006.01070.x.

7. Makarieva, A. M. Biotic pump of atmospheric moisture as driver of the hydrological cycle on land / A. M. Makarieva, V. G. Gorshkov // Hydrology and Earth System Sciences. - 2007. - Vol. 11 (2). - P. 1013-1033. - DOI 10.5194/ hess-11-1013-2007.

8. Annual Climate Statement 2019 / Bureau of Meteorology. - Australia, 2020. - URL: http://www.bom.gov.au/ climate/current/annual/aus/

9. Gorshkov, V. G. Key ecological parameters of immotile versus locomotive life / V. G. Gorshkov, A. M. Makarieva // Russian Journal of Ecosystem Ecology. - 2020. - Vol. 5 (1). - P. 1-18. - DOI 10.21685/2500-0578-2020-1-1.

10. White, C. R. Metabolic scaling in animals: methods, empirical results, and theoretical explanations / C. R. White, M. R. Kearney // Comprehensive Physiology. - 2014. - Vol. 4 (1). - P. 231-256. - DOI 10.1002/cphy.c110049.

11. Historical records reveal the distinctive associations of human disturbance and extreme climate change with local extinction of mammals / X. Wan, G. Jiang, C. Yan, F. He, R. Wen, J. Gu, X. Li, J. Ma, N. C. Stenseth, Z. Zhang // Proceedings of the National Academy of Sciences U.S.A. - 2019. - Vol. 116 (38). - P. 19001-19008. DOI 10.1073/pnas.1818019116.

12. Brooks, D. R. Evolution as Entropy. Toward a Unified Theory of Biology / D. R. Brooks, E. O. Wiley. - Chicago : University of Chicago Press, 1988. - 429 p.

13. Dubilier, N. Symbiotic diversity in marine animals: the art of harnessing chemosynthesis / N. Dubilier, C. Bergin, C. Lott // Nature Reviews Microbiology. - 2008. - Vol. 6 (10). - P. 725-740. - DOI 10.1038/nrmicro1992.

14. Atmospheric trace gases support primary production in Antarctic desert surface soil / M. Ji, C. Greening, I. Vanwonterghem, C. R. Carere, S. K. Bay, J. A. Steen, K. Montgomery, T. Lines, J. Beardall, J. van Dorst, I. Snape, M. B. Stott, P. Hugenholtz, B. C. Ferrari // Nature. - 2017. - Vol. 552. - P. 400-403. DOI 10.1038/nature25014.

\section{References}

1. Ortega y Gasset J. The Revolt of the Masses. New York: W.W. Norton \& Co, 1932.

2. Epstein D. Range: How Generalists Triumph in a Specialized World. London: Macmillan, 2019.

3. Makarieva A. M., Gorshkov V. G., Li B.-L. Energetics of the smallest: do bacteria breathe at the same rate as whales? Proceedings of the Royal Society B: Biological Sciences. 2005, vol. 272 (1577), pp. 2219-2224. DOI: $10.1098 / \mathrm{rspb} .2005 .3225$.

4. Makarieva A. M., Gorshkov V. G., Li B.-L., Chown S. L., Reich P. B., Gavrilov V. M. Mean mass-specific metabolic rates are strikingly similar across life's major domains: Evidence for life's metabolic optimum. Proceedings of the National Academy of Sciences U.S.A. 2008, vol. 105 (44), pp. 16994-16999. DOI: 10.1073/ pnas.0802148105.

5. Hatton I. A., Dobson A. P., Storch D., Galbraith E. D., Loreau M. Linking scaling laws across eukaryotes. Proceedings of the National Academy of Sciences U.S.A. 2019, vol. 116 (43), pp. 21616-21622. DOI: 10.1073/ pnas. 1900492116.

6. Makarieva A. M., Gorshkov V. G., Li B.-L., Chown S. L. Size- and temperature-independence of minimum lifesupporting metabolic rates. Functional Ecology. 2006, vol. 20, pp. 83-96. DOI:10.1111/j.13652435.2006.01070.x.

7. Makarieva A. M., Gorshkov V. G. Biotic pump of atmospheric moisture as driver of the hydrological cycle on land. Hydrology and Earth System Sciences. 2007, vol. 11 (2), pp. 1013-1033. DOI: 10.5194/hess-11-1013-2007.

8. Bureau of Meteorology, Australia. 2020. Annual Climate Statement 2019. Available from: http://www.bom.gov.au/climate/current/annual/aus/

9. Gorshkov V. G., Makarieva A. M. Key ecological parameters of immotile versus locomotive life. Russian Journal of Ecosystem Ecology. 2020, vol. 5 (1), pp. 1-18. DOI: 10.21685/2500-0578-2020-1-1.

10. White C. R., Kearney M. R. Metabolic scaling in animals: methods, empirical results, and theoretical explanations. Comprehensive Physiology. 2014, vol. 4 (1), pp. 231-256. DOI: 10.1002/cphy.c110049.

11. Wan X., Jiang G., Yan C., He F., Wen R., Gu J., Li X., Ma J., Stenseth N. C., Zhang Z. Historical records reveal the distinctive associations of human disturbance and extreme climate change with local extinction of mammals. 
Proceedings of the National Academy of Sciences U.S.A. 2019, vol. 116 (38), pp. 19001-19008. DOI: $10.1073 /$ pnas.1818019116.

12. Brooks D. R., Wiley E. O. Evolution as Entropy. Toward a Unified Theory of Biology. Chicago: University of Chicago Press, 1988, 429 p.

13. Dubilier N., Bergin C., Lott C. Symbiotic diversity in marine animals: the art of harnessing chemosynthesis. Nature Reviews Microbiology. 2008, vol. 6 (10), pp. 725-740. DOI: 10.1038/nrmicro1992.

14. Ji M., Greening C., Vanwonterghem I., Carere C. R., Bay S. K., Steen J. A., Montgomery K., Lines T., Beardall J., van Dorst J., Snape I., Stott M. B., Hugenholtz P., Ferrari B. C. Atmospheric trace gases support primary production in Antarctic desert surface soil. Nature. 2017, vol. 552, pp. 400-403. DOI: 10.1038/nature25014. 